\title{
CCL2 wt Allele
}

National Cancer Institute

\section{Source}

National Cancer Institute. CCL2 wt Allele. NCI Thesaurus. Code C49745.

Human CCL2 wild-type allele is located within $17 q 11.2-q 12$ and is approximately $2 \mathrm{~kb}$ in length. This allele, which encodes C-C motif chemokine 2 protein, is involved in the mediation of immune cell chemotaxis during tissue injury. 